\title{
The Influence of Moral Reasoning and Gender towards Whistleblowing Intention
}

\section{Mayar Afriyenti}

Dept. of Accounting, Faculty of Economics, Universitas Negeri Padang, Padang, Indonesia, $\square$ (e-mail) mayarafriyenti@fe.unp.ac.id

\begin{abstract}
Whistleblowing has been regarded as one of the most effective ways to prevent corruption. Various economic, psychological and ethical factors have been investigated as triggering a person's desire to take whistleblowing action. This research aims to empirically examine the influence of moral reasoning and gender on whistleblowing intention in the context of local government public servants. The research was conducted using a quasi-experiment approach. Variable of moral reasoning was measured using Mach-IV and gender was identified based on demographic data of the participants. The data were analyzed using one-way ANOVA. The results show that the level of moral reasoning significantly influences whistleblowing intention, while gender does not. The findings imply the importance of government institutions to build and foster moral standards and codes of conduct in order to support corruption and fraud prevention through whistleblowing mechanisms.
\end{abstract}

Keywords: moral reasoning, gender, whistleblowing, public sector, local government

\section{Introduction}

The Association of Certified Fraud Examiners (ACFE) states that there are three forms of fraud, namely, misuse of assets, fraudulent financial reporting, and corruption. The fact that Indonesia as one of the country with a high level of corruption in the world indicates the number of irregularities that occur both at the level of government organizations and the private sector. In Indonesia, there are many cases of misuse of assets, fraud in financial reports, corruption, extortion, bribery, and other unethical actions that violate the rules (ACFE, 2016; Diani and Narsa, 2017). Fraud is recognized as a serious socio-economic problem in the world because of the magnitude of the impact of losses incurred and whistleblowing has become an important mechanism to combat it (Darjoko, 2016). Many countries, including Indonesia, have arranged and encouraged every private or public organization to establish a whistleblowing system to prevent and expose a fraud (OJK, 2014).

The digital era is currently the government must be able to make the most of existing technology. Digital solutions can improve third-party due diligence and allow it to track and strengthen compliance within global supply chains. The whistleblowing system has been regarded as an important form or policy practice in fraud control in the digital era. Whistleblowing will prevent potential fraud in business and financial transactions in the development of digital technology. ACFE's global study results showed the facts about the role of whistleblowing as preventive and monitoring mechanism in fraudulent disclosure (ACFE 2016, 2014, 2012b). The whistleblowing system is increasingly gaining attention as fraud continues to be the source of the problems affecting various organizations with very serious loss impacts.

Many studies on whistleblowing has been done. Most of these prior studies try to outline the factors that influence or encourage individuals to do whistleblowing. Some of the economic and psychological factors identified as triggers of a person doing whistleblowing such as the seriousness of the problem, personal responsibility, personal cost, retaliation rate, personal reward, compliant success, and cost and benefit considerations (Ayers \& Kaplan; 2005; Liyanarachchi \& Newdick; 2009, Brewer \& Selden; 1998; Gundlach, Douglas \& Martinko; 2003; Keenan, 1990). In addition to economic and psychological factors, the tendency to conduct whistleblowing is also linked to ethical issues. More specifically, the 
ethical factors expressed include moral equity, personal responsibility, and moral reasoning. One factor that has not yet been examined for its role in exposing one's intentions to whistleblowing is the gender factor, whereas, in ethical studies in other fields, such as taxation (such as Chung \& Trevedi, 2003), gender issues are considered to be decisive. Taylor and Curtis (2013) argue that gender may be able to create inconsistent influences in ethical decision making. In response to these calls, this study seeks to complement ethical literature in whistleblowing by examining the effect of moral reasoning and gender toward whistleblowing intention. The examination of the effects of moral reasoning in this study uses Machiavellianism measure (Mach-IV), in contrast to previous studies conducted by Liyanarachchi and Newdick (2009) which is used DIT Score from Rest (1977). According to Ghosh and Crain (1996), Machiavellianism is a valid instrument to measure individual moral reasoning.

This study examines whistleblowing intentions by local government employees for several reasons. First, whistleblowing research has so far invoked whistleblowing intentions to auditors, both internal and external auditors (such as Taylor \& Curtis, 2013; Darjoko, 2016; Diani \& Narsa, 2017). Second, local government in Indonesia is considered as one of the institutions with an alarming level of corruption. No less than 100 Heads of Regions and/or head of the governmental unit who are involved in corrupt practices and are caught by the anti-corruption body.

In this study, the research hypotheses proposed are as follows:

$\mathrm{H}_{1}$ : The level of moral reasoning of the local government staff has a significant influence on their whistleblowing intention

$\mathrm{H}_{2}$ : Gender of the local government staff has a significant influence on their whistleblowing intention

\section{Methods}

The study was conducted using a quasi-experimental design. The participants in this experiment were civil servants in Pasaman Regency (Kab. Pasaman). Participants are selected based on 2 (two) criteria that include minimum education of Diploma 1 and working period of at least 5 (five) years.

The experimental task in this research was the case of fraud in the procurement of government goods and services. The independent variables in this study were moral reasoning and gender. Moral reasoning was measured using Machiavelism (Mach-IV) while gender was identified as male and female based on respondents' demographic data.

The Mach-IV measure consists of 20 statement items, where the statements on items 1,3,4,6,7,9,12, 16,18 , and 19 are positive items and apart from the item each score is a negative item (reverse measured). To determine the level of moral reasoning of Mach-IV measure, the data is split using mean.

The dependent variable is whistleblowing intention which is measured using a Likert scale on a scale of 1-7. The higher the respondent gives the scores, indicates a higher whistleblowing intention, and vice versa.

The objective of this study is to determine the effect of moral reasoning and gender toward whistleblowing intention. Since this study would like to scrutiny the difference in response of two levels of moral reasoning (high and low) then the level of moral reasoning is split down on a mean basis. Thus, respondents will be classified as high moral reasoning level group and low level of moral reasoning group. Data were analyzed using one-way ANOVA.

\section{Results and Discussion}

A total of 156 questionnaires were administered and resulted with 128 returned responses. Of the 128, 119 questionnaires can be processed, while the other 9 were eliminated because of incomplete response from participants. The Demographic data of respondents showed there were 65 male respondents $(54.62 \%)$ and 54 female respondents $(45.38 \%)$. There are two hypotheses in this study. Hypothesis 1 predicts that the level of moral reasoning affects the whistleblowing intention. In other words, the staff of the local government with higher moral reasoning levels will show a stronger 
whistleblowing intention than those with lower levels of moral reasoning. Meanwhile, hypothesis 2 predicts that male have a stronger whistleblowing intention than female. Descriptive statistics for the first variables are presented in table 1 below.

Table 1 Descriptive Statistics for Moral Reasoning

\begin{tabular}{lrrrrrr}
\hline & N & Mean & $\begin{array}{c}\text { Std. } \\
\text { Deviation }\end{array}$ & $\begin{array}{c}\text { Std. } \\
\text { Error }\end{array}$ & \multicolumn{2}{c}{$\begin{array}{c}\text { 95\% Confidence Interval } \\
\text { for Mean }\end{array}$} \\
\cline { 3 - 7 } & & & & & $\begin{array}{c}\text { Lower } \\
\text { Bound }\end{array}$ & $\begin{array}{c}\text { Upper } \\
\text { Bound }\end{array}$ \\
\hline 0 & 60 & 4,5667 & 0,83090 & 0,10727 & 4,3520 & 4,7813 \\
\hline 1 & 59 & 5,0678 & 1,12747 & 0,14678 & 4,7740 & 5,3616 \\
\hline Total & 119 & 4,8151 & 1,01653 & 0,09318 & 4,6306 & 4,9997 \\
\hline
\end{tabular}

As can be seen from table 1 , and consistent with $\mathrm{H}_{1}$, the average whistleblowing intention was higher for the local government staff with higher moral reasoning on a scale of 5, 06 (standard deviation $1.127)$ than staff with lover moral reasoning level $(4.56$, standard deviation $=0.830)$. This difference that show the main effect of moral reasoning is statistically significant $(\mathrm{F}=7,636 ; \mathrm{p}=0,007)$, thus, $\mathrm{H}_{1}$ is supported. The ANOVA results are showed in Table 2 below.

Table 2 ANOVA Results for Moral Reasoning Influence on Whistleblowing Intention

\begin{tabular}{lrrrrc}
\hline & \multicolumn{1}{c}{$\begin{array}{c}\text { Sum of } \\
\text { Squares }\end{array}$} & \multicolumn{1}{c}{ df } & Mean & & \\
& Square & F & Sig. \\
\hline Between Groups & 7,471 & 1 & 7,471 & 7,636 & 0,007 \\
\hline Groups & 114,462 & 117 & 0,978 & & \\
\hline Total & 121,933 & 118 & & & \\
\hline
\end{tabular}

Meanwhile, descriptive statistics for gender are presented in Table 3 below. The results show that males have average intention to conduct whistleblowing on the scale of 4,846 (standard deviation 1,034) while females have average intention to conduct whistleblowing on 4.703 scales (standard deviation $1,002)$. This difference is not statistically significant $(F=0.575 ; \mathrm{p}=0.450)$.

Table 3 Descriptive Statistics for Gender

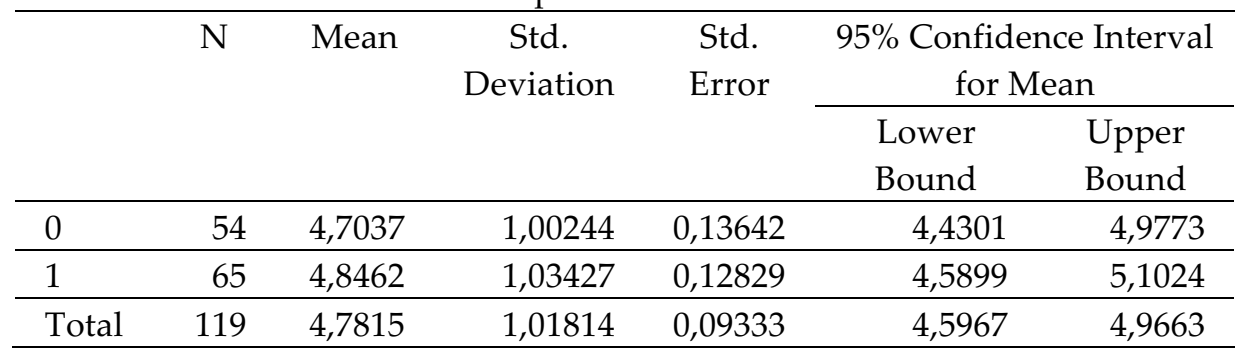

The descriptive statistics above indicate is result indicate that there are no differences in whistle blowing intention between males and females. This is consistent with ANOVA results in Table 4 that show $\mathrm{H}_{2}$ is not supported.

Table 4 ANOVA Results for Gender Influence on Whistleblowing Intention

\begin{tabular}{lrrrrc}
\hline & Sum of Squares & df & Mean Square & F & Sig. \\
\hline Between Groups &, 599 & 1 & 0,599 & 0,575 & 0,450 \\
\hline Groups & 121,721 & 117 & 1,040 & & \\
\hline Total & 122,319 & 118 & & & \\
\hline
\end{tabular}

\section{Results and Discussion}

Hypothesis 1 predicts that differences in the level of moral reasoning result in differences in whistleblowing intention. The study found that individuals with higher moral reasoning level showed a higher whistleblowing intention than individuals with lower moral reasoning level. The results of 
this study are consistent with those Welton et al. (1994), Wilopo (2006), Ponemon (1992), Liyanarachhi and Newdick (1999), and Diani and Narsa (2017).

The findings suggest that individuals with high morals are more likely to blow the whistle, and thus, developing individual's moral reasoning through code of ethics socialization and enforcement will help to encourage ethical behavior. The results raise expectation that by paying attention to ethical standards and codes of conduct in local governance institutions, fraud and corruption practices can be prevented and eradicated. This condition will support the implementation of an integrated whistleblowing system.

The study found that gender did not influence whistleblowing intention among local governments' public servants. The findings of prior research show that gender does not always affect ethical behavior (Goldman, 2001). In certain situations, females are more likely to behave ethically than male as found in Scholz and Pinney (1995), and Baron et al. (1992) but not so in another context as found by Taylor and Curtis (2013). The findings have implications for the importance of finding the setting under what conditions gender may influence individual ethical decisions.

\section{Conclusions}

This study aims to empirically examine the influence of moral reasoning and gender on whistleblowing intention in the context of local government public servants. The study was conducted using a quasi-experiment design. Moral reasoning was measured using Mach-IV and gender was identified based on demographic data of the participants. The data were analyzed using one-way ANOVA.

The results of the study show that the level of moral reasoning of the local government staff has a significant influence on whistleblowing intention, while gender does not influence the individual's intention blow the whistle. The findings imply that the moral consciousness of local government staff needs to be continuously built so as to create a work environment that supports the prevention and eradication of corruption through whistleblowing mechanisms. Guidance and development of moral standards also need to be supported by formalizing the code of ethics so that the local government staff always feel tied to its ethical obligations and moral standards.

There are some limitations in this study that need to be of concern. First, the procurement of goods and services might be not too relevant for the study refers to the centralization of procurement through Procurement Services Unit. This condition indicates that not all local government officials know the procurement processes. Second, whistleblowing decisions are not only triggered by ethical issues, therefore future research needs to combine ethical factors with other factors such as whistleblowing channel, recipients' accountability and organizational response.

\section{References}

ACFE. (2016). Report to the Nations on Occupational Fraud and Abuse. Associations of Certified Fraud Examiners.

Badan dan Pendidikan Pelatihan Keuangan Kementrian Keuangan. (2013). The Role 'Whistleblower' in Corruption Erradication. Retrieved from http://www.bppk.kemenkeu.go.id/ publikasi/artikel/168-artikelpengembangan-sdm/10977-peran-peniup-peluit-dalampemberantasankorupsi

Bernardi, R. A. (1994). Fraud detection: The effect of client integrity and competence and auditor cognitive style. Auditing: A Journal of Practice \& Theory, 13(2), 68-84.

Chung, Janne \& Trivedi, V. U. (2003). The effect of friendly persuasion and gender on tax compliance behavior. Journal of Business Ethics, 47(2), 133-145.

Darjoko, F. J \& Nahartyo, E. (2016). The effect of fraud type and anonymity on investigation decision due to whistleblowing by Internal Auditor. Proceeding National Accounting Symposium XVIII, Bandar Lampung. 
Diani, R. C., \& Narsa, I. M. (2017). Moral reasoning level and role conflict: Experimental study for whistleblowing behavior model of internal government auditor. Tata Kelola dan Akuntabilitas Keuangan Negara, 3, 131-149.

Ghost, Dipankar \& Crain, Terry L. (1996). Experimental investigation of ethical standards and perceived probability of audit on international noncompliance. Behavioral Research in Accounting, 8, Supplement.

Liyanarachchi, G., \& Newdick, C. (2009). The impact of moral reasoning and retaliation on whistleblowing: New Zealand Evidence. Journal of Business Ethics, 89, 37-57.

Maroney, J. J., \& McDevitt, R. E. (2008). The effects of moral reasoning on financial reporting decisions in a post-Sarbanes-Oxley environment. Behavioral Research in Accounting, 20(2), 89-110.

Near, J. P. \& Miceli, M. P. (1985). Organizational dissidence: The case of whistle-blowing. Journal of Business Ethics, 4, 1-16.

Otoritas Jasa Keuangan (OJK). (2014). Roadmap Tata Kelola Perusahaan Indonesia. http://www.ojk.go.id

Ponemon, Lawrence A. (1994). Whistle-blowing as an internal control mechanism-individual dan organizational considerations. Auditing: A Journal of Practice \& Theory,13(2), 118-130.

Rehg, M. T., M. P. Miceli, J. P. Near, \&Van Scotter, J. R. (2008). Antecedents and outcomes of retaliation against whistleblowers: Gender differences and power relationships. Organization Science,19 (2), 221-240.

Rest, J. R. (1979). Revised manual for the Defining Issues Test (DIT): An objective test for moral judgment development. Minneapolis, Minn.: Minnesota Moral Research Projects.

Rest, J. Morality, in P. H. Mussen (ed.). (1983). Handbook of Child Psychology. Vol. III edited by J. Flavell and E. Markman. Wiley: New York.

Rocha, E. and B. H. Kleiner. (2005). To blow or not to blow the whistle? That is the question. Management Research News, 28(11/12), 80-87.

Setyawati, I., Ardiyani, K., \& Ragil, Catur Sutrisno. (2015). The factors influencing internal whistleblowing intentions. Jurnal Ekonomi dan Bisnis, 17(2).

Stedham, Y., Yamamura, J. H., \& Beekun, R. I. (2007). Gender differences in business ethics: Justice and relativist perspectives. Business Ethics: A European Review, 16, 163-174

Taylor, E. Z., \& Curtis, M. B. (2013). Whistleblowing in audit firm: Organizational response and power distance. Behavioral Research in Accounting, 25(2), 21-43.

Welton, R. E., Lagrone, R. M., \& Davis, J. R. (1994). Promoting the moral development of accounting graduate students. Accounting Education Journal, 3(1), 35-50.

Wilopo. (2006). Analisis faktor-faktor yang berpengaruh terhadap kecenderungan kecurangan akuntansi: Studi pada perusahaan publik dan Badan Usaha Milik Negara (BUMN) di Indonesia. The Indonesian Journal of Accounting Research, 9(3), 346-366. 